\section{Bondarenko Y., Kovalchuk $\mathbf{0 .}$ Loginova $Y$., Artiukh K.}

\title{
RISK ANALYSIS ON TECHNICAL SAFETY OF PRODUCTION OF WELDED STRUCTURES USING NON-DESTRUCTIVE TEST AND TECHNICAL DIAGNOSTICS
}

Об’єктом дослідження є зварні конструкиї та їх виробництво.

Ризик є завжди, але очевидно, що прийняття рішень щодо його мінімізацї та усунення потребує структурованого і системного підходу. Наприклад, керівникам вищої, середньої та лінійної ланок потрібно постійно аналізувати ризики, пов'язані з небезпеками, які виникають у дуже складних ситуаціях на зварювальному виробництві.

У роботі побудовано алгоритм утворення ризику при експлуатащії зварних конструкцій. Запропоновано процесний підхід з метою аналізу відхилення процесів проектування, виробництва та обслуговування. Визначено показники граничних станів зварної конструкцї від механічних дій та показники якості корозійних впливів. Підібрано розрахункові формули швидкості (імовірності) досягнення граничних станів від механічних дій. Для аналізування комбінації дій рекомендовано застосовувати метод сіток Байєса. Встановлено, що одним з основних завдань системи менеджменту якості зварювального виробництва згідно ДСТУ ISO 9001:2015 є забезпечення виявлення потенційних невідповідностей в системі зварювального виробництва і попередження їх виявлення за допомогою менеджменту ризику. Відхилення прочесів системи менеджменту є причинами утворення браку продукції, що випускається, та виникнення ризику аварійної ситуацї на виробнищтві. Успіх менеджменту ризиків буде залежить від результативності структури менеджменту, яка забезпечує обтрунтування $і$ заходи, які інтегрують його по всьому зварювальному підприємству по всім рівням. Структура допомагає впровадженню результативного менеджменту ризиків через провадження процесів менеджменту ризиків та неруйнівного контролю і технічної діагностики на різних рівнях і рамках конкретного контексту підприємства. Структура гарантує, що інформація про ризик, отримана в процесі менеджменту ризику відповідним чином, використовується як основа для прийняття рішення і призначення відповідальних за результат на всіх відповідних рівнях зварювального виробництва.

Ключові слова: умови виробництва, технологічна документація, система контролю, людський фактор, морально-психологічний клімат, ризик-менеджмен, управління ризиками.

Received date: 21.10 .2019

Accepted date: 11.11.2019

Published date: 30.12 .2019
Copyright (C) 2019, Bondarenko Y., Kovalchuk O., Loginova Y., Artiukh K. This is an open access article under the CC BY license (http://creativecommons.org/licenses/by/4.0)

\section{Introduction}

No manufacturer of welding equipment can guarantee high-quality welding if a low-quality wire is used or the gas parameters do not meet the standards. Everything is being done so that the characteristics of the equipment correspond to the most stringent requirements of regulatory documents and the market [1,2]. Even with the current difficult situation in the European economy, they do not go for cheaper products due to the transfer of production to countries with cheap labor, they do not replace expensive materials with low-grade ones. All devices use only European components and those made at production sites in Austria, Wales, the Czech Republic and the USA. Ukrainian entrepreneurs rarely venture into heavy investments with a distant eye. The reasons are clear: we have every year, then some kind of stress. But those who seek to gain a foothold in the market and become competitive have already seen that the costs of equipment of this class are justified [3, 4]. However, recently there has been another problem: fewer workers want to be welders, at least in Ukraine. As a result, many enterprises lack qualified personnel. This is the government's concern, and this year a number of educational institutions allocated funds for the formation of welder training centers. To the credit of Ukraine, I must say that most of these centers are equipped with new technology. Young people will not study in the pictures of yesterday and posters, but on the advanced modern equipment. Therefore, research on welding production remains relevant. Thus, the object of research is welded structures and their production. And the aim of research is analysis of the problems of welding production and the operation of welded structures.

\section{Methods of research}

Analysis of literature shows that the limit state from mechanical stresses on a welded structure is divided into two groups, in turn, has subgroups [5-8]. 
The first group contains the limiting states, the transition through which leads to the complete unsuitability of the object (the basis of the structure, structure or element) for operation and for which the inferior states can be:

- destruction of any nature (viscous, brittle, as a result of fatigue);

- loss of shape stability;

- loss of stability;

- transition to a variable system; qualitative change

in configuration;

- other phenomena in which there is a need

to cease operation (for example, the occurrence of perforation of the wall of a container with toxic substances or excessive movement of the base during planting of loose soils).

Limit states of this group may be related to violation of the requirements for conservation or the possibility of the existence of an object or non-compliance with safety requirements for people and the environment. Achievement of the limit state of the first group is classified as failure-failure (failure, which immediately causes accidents and losses) [7].

The second group includes limit states that impede the normal operation of the facility or reduce its durability in comparison with the established period of operation and for which outside the limit state is:

- excessive excess or rotation of some points of the

structure, unacceptable fluctuations (excessive value of amplitude, frequency, speed, acceleration);

- formation and disclosure of internal defects, their achievement of the maximum values of opening or length (cracks in critical structures are not allowed) by nondestructive testing and technical diagnostics (NT and TD);

- loss of shape stability in the form of local deformation; - damage from corrosion or other types of physical wear, which lead to the need to limit operation due to a decrease in the life of the facility according to information received from the NT and TD (Fig. 1).

Based on the foregoing, the following conclusions can be drawn:

1. Products for welding production are divided into 4 groups.

2. The indicators of the ultimate state of the welded structure from mechanical stresses and the quality indicators of corrosion effects on operational safety are determined.

3. It has been established that one of the main tasks of the quality management system of welding production (according to DSTU ISO 9001:2015) is to identify potential inconsistencies in the welding production system and prevent their detection using risk management using NT and TD. Deviations of the processes of the management system are the reasons for the formation of a shortage of products and the risk of an emergency at work.

4. Risk management is an indispensable part of the management process, as it is fundamental to the welding enterprise. Therefore, at all levels and in all areas: the quality of work on welding and NT and TD, labor safety, ecology, energy saving, it is necessary to meet national and international standards.

Welding production is confronted with internal and external factors and influences that create uncertainties as to whether they will be able to achieve their goals, as well as the timing of achieving these goals. The effect of such uncer- tainty on welding production is a risk [8, 9]. All activities of the welding enterprise include risk. Welding production carries out risk management because of its identification, analysis and by assessment, risk should be changed by processing, NT and TD, in order to meet the established risk criteria. During this process, it communicates and consults with stakeholders. At the same time, monitoring and viewing of risk and controls are carried out, which change the level of risk to ensure that further risk processing during the operation of welded structures is not required [10].
Qualitative analysis

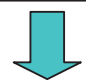

\section{L}

e the greatest impact ation and are used as

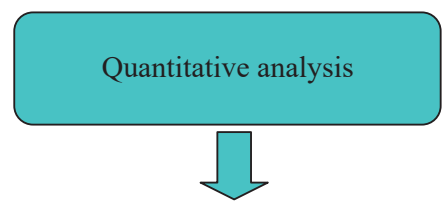

Carried out using statistical, analytical methods, methods of expert assessments, methods of analogues, etc.
Fig. 1. Methods of risk management in the enterprise

\section{Research results and discussion}

In the course of the work, it is found that the risk of production during the life cycle is associated with:

1. The purpose of the construction.

2. Production factors, namely, process mismatches:

1) design;

2) production;

3) installation;

4) operational maintenance;

5) unreliability and uncertainties of the test processes during the life cycle of items 1-4.

3. Physical effects on the structure. Analysis of the design purpose contains:

- operating conditions (action on the structure);

- legislative requirements for the design and analysis of risks;

- level of quality according to the results of NT and TD of similar products on the market;

- analysis of the risks of human exposure during the production and operation of the structure;

- analysis of the risk of environmental impact during production and operation;

- risk analysis of the use of the welded structure for other purposes;

- analysis of residual risks after the actions of personnel in emergency situations.

One of the main tasks of the welding production quality management system is to ensure the identification of potential inconsistencies and to prevent their detection with the help of NT and TD. Deviation of the management system processes are the causes of the shortage of products [11].

The relationship between the risk of non-conforming products as a result of the operation of an inappropriate quality management system for the design of welded structures, production, maintenance and the main factors of external threats is proposed (Fig. 2).

Quality management standards consider risks as the probable deviation of each of the processes, which describes the full activity of the welding enterprise in the management, supply, production of structures, monitoring 
and NT and TD. Therefore, let's recommend identifying the risks inherent in each of the processes. A process approach is proposed. This will allow to determine both the owner of the process and the owner of the risk and those responsible for the process with which the occurrence of risk is associated. And it will also allow to establish the processes preceding this process and determine causal relationships in case of a risk in the manufacture and operation of the structure [13].

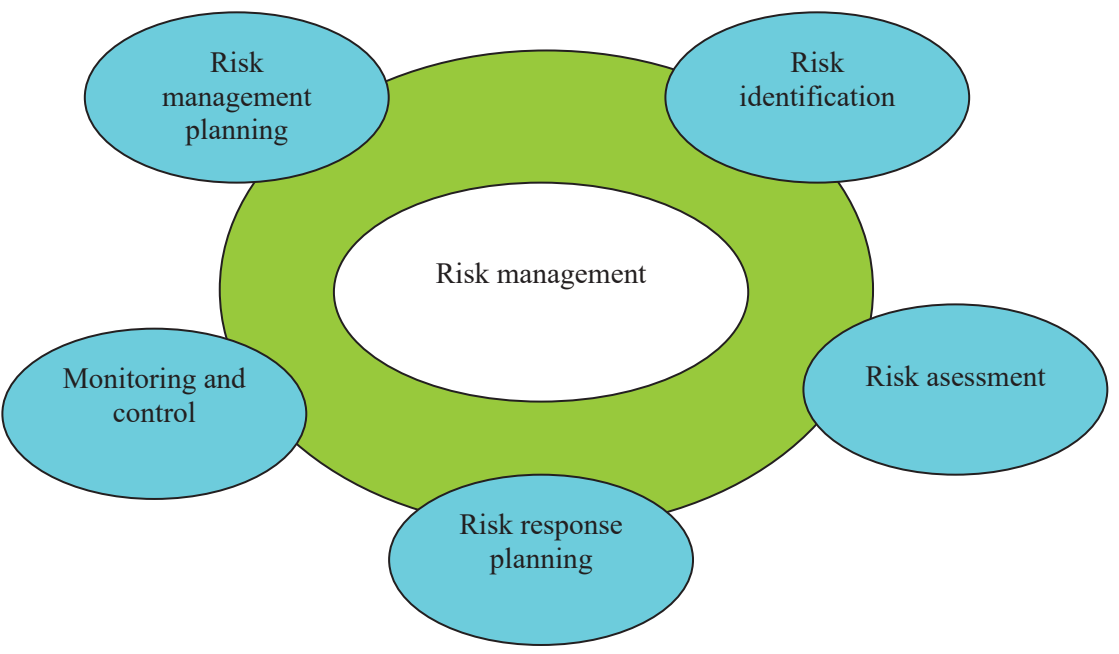

Fig. 2. Risk management [12]

The welded structure, which is operated, is subject to physical effects, they are mechanical, thermal and chemical in nature. During the operation of building structures, mechanical effects on the structure and corrosive effects leading to corrosion damage to the metal can be considered significant impacts. The risk of operation of the structure is considered as the probability of failure and associated losses. Failure may be considered a change in the properties of the structure to a more extreme state.

The limiting conditions of the second group may be associated with violation of the requirements for the use of a welded structure without restrictions, personnel service capabilities, improper use of NT and TD, appearance, and modernization capabilities. Often these limit states are classified as «failure is an obstacle» [14].

The condition for ensuring reliability, i. e. absenteeism to the limit state, is written by an inequality of the form:

$$
g\left(G_{d}, f_{e}, a_{d}, C, \gamma_{n}, \gamma_{d}, T_{e f}\right) \geq 0
$$

where $g(o)$ - such a function of the system parameters for which $g(o)<0$ means the achievement of a transboundary state; $G_{d}, f_{e}, a_{d}$ - calculated values of loads, strength characteristics of materials or abrasive materials and geometric characteristics of the structure, respectively; $C$ - restriction on the parameter that is monitored (for example, the permissible maximum disclosure of a defect); $\gamma_{n}$ - reliability coefficient for responsibility (liability coefficient), taking into account the significance of the structure and the facility as a whole, as well as the possible consequences of failure, and is taken into account as a factor to the calculated value of the load; $\gamma_{d}-$ reliability coefficient of the model, taking into account the uncertainty of the design scheme and other similar cir- cumstances (for example, the sensitivity of the structure to local damage, initial imperfections, increased wear rate). It is taken as a factor to the calculated value of the load (Fig. 3).

In order to determine the speed of the design's possible achievement of a critical state by corrosion (or the probability of reaching the limit state during Tef), it is recommended to use the following quality assessment indicators:

1. Mass - characterizes the change in the mass of the sample of material in the corrosion results $\left(\mathrm{g} / \mathrm{m}^{2} \cdot \mathrm{h}\right)$ :

$$
K_{m}^{ \pm}=\frac{m_{1}-m_{2}}{S \cdot \tau}
$$

where $m_{1}, m_{2}-$ mass of material in accordance with and after corrosion; $S$ - surface area of the material, $\mathrm{m}^{2}$; $\tau$ - time.

The relationship between positive and negative mass metrics:

$$
K_{m}^{-}=K_{m}^{+} \frac{n_{o}-A_{M}}{n_{M} \cdot A_{o}}
$$

where $n_{0}, n_{M}$ - the valencies of the oxidizing agent and the metal, respectively; $A_{o}, A_{M}$ - the atomic masses of the oxidizing agent and the metal, respectively.

2. Deep (allows to evaluate the corrosion depth of the metal $(\mathrm{mm} / \mathrm{h}))$ :

$$
K_{p}=8.76 \frac{m_{1}-m_{2}}{\rho \cdot S \cdot \tau},
$$

where $\rho$ - the metal density $\mathrm{g} / \mathrm{cm}^{3}$.

The relationship between depth and mass corrosion:

$$
K_{p}=8.76 \frac{K_{m}^{-}}{\rho} .
$$

3. Volumetric - in the case of metal corrosion in acids, the corrosion rate can be determined by the amount of released hydrogen $\left(\mathrm{cm}^{3} / \mathrm{cm}^{2} \cdot\right.$ year $)$ :

$$
K_{y}=\frac{V \cdot 273\left(P-P_{\mathrm{H}_{2} \mathrm{O}}\right)}{S \cdot \tau(273+t) \cdot 760},
$$

where $P, P_{\mathrm{H}_{2} \mathrm{O}}$ - respectively, atmospheric pressure during the experiments and the pressure of saturated water vapor at the measurement temperature, $\mathrm{mm} \cdot \mathrm{Hg} ; t$ - measurement temperature, ${ }^{\circ} \mathrm{C} ; \mathrm{V}$ - volume of released hydrogen, $\mathrm{cm}^{3}$.

4. Change in electrical resistance $K_{R}$ :

$$
K_{R}=\frac{R_{k}}{R_{o}},
$$

where $R_{o}$ and $R_{k}$ - respectively, the resistance of the material before and after corrosion.

To account for the combination of actions, it is recommended to use the Bayesian network risk analysis method. There is a certain problem of obtaining statistics on possible failure. Failure analysis is carried out according to the results of tests in factory testing laboratories of enterprises of Ukraine. 
On the risk map (Fig. 4), the probability or frequency is displayed along the vertical axis, and the impact force or significance is displayed along the horizontal axis. In this case, the probability of the occurrence of risk increases from bottom to top when moving along the vertical axis, and the influence of risk increases from left to right along the horizontal axis.

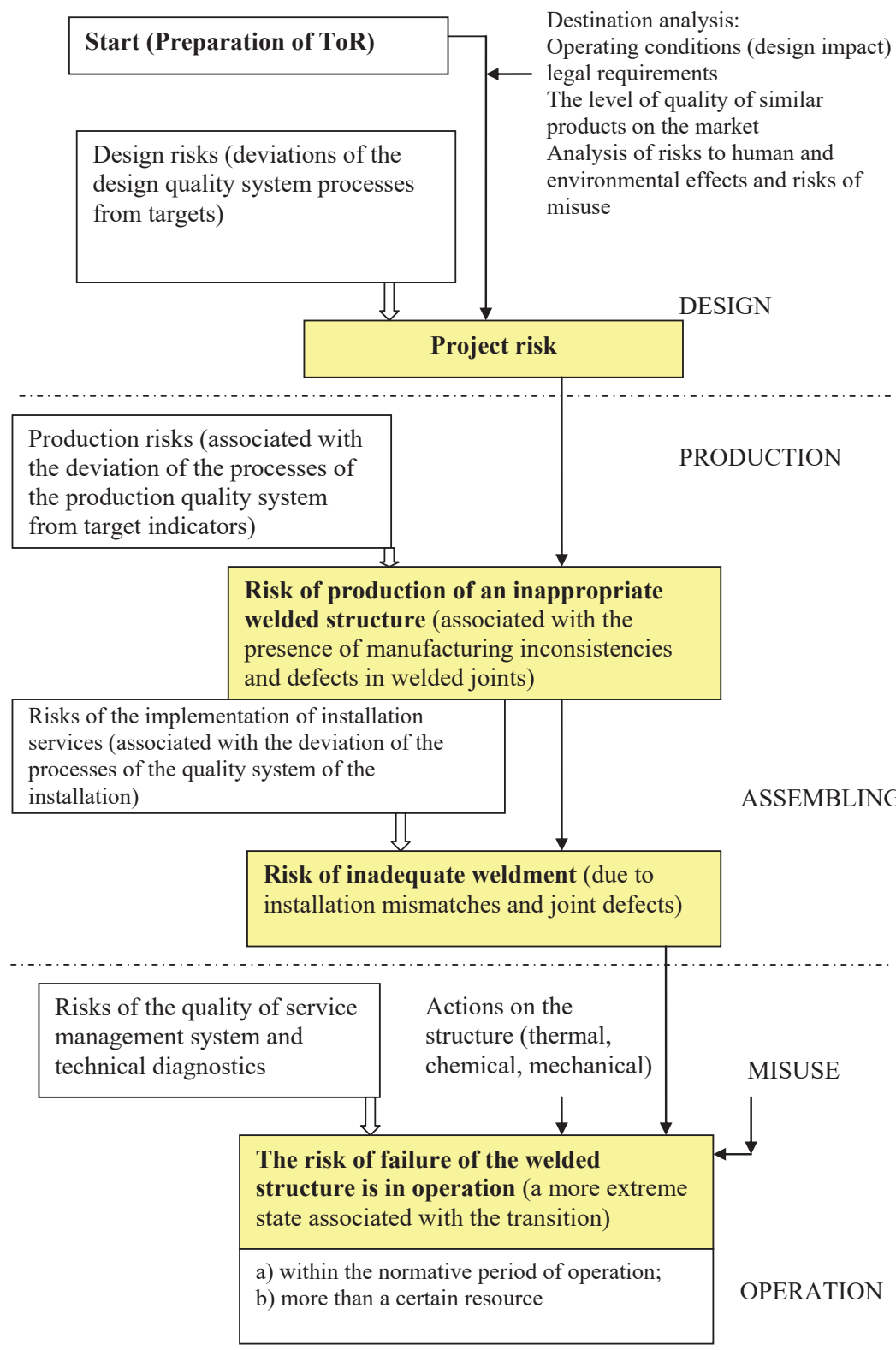

Fig. 3. Algorithm for the occurrence of risk in welded structures (TR - terms of reference)

\begin{tabular}{|l|l|l|l|l|}
\hline 4 Frequent & 4 & 5 & 17 & 16 \\
\hline 3 Possible & 3 & 6 & 9 & 17 \\
\hline 2 Random & 2 & 4 & 6 & 6 \\
\hline 1 Rare & 1 & 2 & 3 & 4 \\
\hline \multirow{2}{*}{} & 1 & 2 & 3 & 4 \\
& Minor & Moderate & Critical & Catastrophic \\
\cline { 2 - 5 } & &
\end{tabular}

Fig. 4. The matrix of risks in welded structures. Risk level defined in the risk profile: 1-2 points - insignificant; 3-4 points - moderate; 6-9 points - critical; 12-16 points - catastrophic
The implementation of risk management and ensuring effectiveness requires a strong and sustainable form of attachment on the part of the enterprise management, as well as strategic and detailed planning to achieve sustainable at all levels [15]. Management needs:

- define and sign a risk management policy;

- ensure the coherence of the enterprise culture and its risk management policies; - provide performance indicators in the field of risk management in the welding industry, which are consistent with the performance of the organization (Fig. 5); - coordinate the goals of risk management with the goals and strategies of the organization;

- ensure compliance with legislative and other mandatory requirements;

- establish responsibility for the result and implementation at the appropriate levels of the enterprise on the basis of NT and TD;

- ensure the allocation of necessary resources for risk management and NT and TD;

- transmit information on the benefits of risk management to all interested parties; - ensure constant compliance of the structure for the implementation of risk management and NT and TD (Fig. 5) [3, 4]. It is recommended to provide documentation of data on identified risks in accordance with the form given in Table 1.

General view of Bayes' theorem:

$$
P(A / B)=\frac{\{P(A) P(B / A)\}}{\sum P\left(B / E_{i}\right) P\left(E_{i}\right)},
$$

where $P(X / Y)$ - probability of the event $X$; $E_{i}-i$-th event.

In the simplest form, Bayes' theorem for two types of action can be written [16]:

$$
P(A / B)=\frac{\{P(A) P(B / A)\}}{\sum P(B)} .
$$

It is established that one of the main tasks of the quality management system of welding production is to ensure the identification of potential discrepancies in welded structures and in the welding production system. To prevent their identification, risk management using NT and TD is used. Deviations of the processes of the management system are the reasons for the formation of a shortage of products and the risk of an emergency at work [2, 17]. Risk management is an essential part of the management process. This is fundamental for the welding company at all levels and in all areas. Particularly important is the quality of the work on welding and NT and TD, labor safety, the environment, energy conservation in accordance with national and international standards. 


\begin{tabular}{|c|c|c|}
\hline Stage 1 & $\begin{array}{l}\text { Qualitative analysis } \\
1 \text { Identification of the full range of risks } \\
2 \text { Description of risks } \\
3 \text { Classification and distribution into groups } \\
4 \text { Analysis of initial assumptions }\end{array}$ & Aim - risk identification \\
\hline Stage 2 & $\begin{array}{l}\text { Quantitative analysis } \\
1 \text { Formalization of uncertainties } \\
2 \text { Calculation of risks } \\
3 \text { Risk documentation }\end{array}$ & Aim - risk measurement \\
\hline Stage 3 & $\begin{array}{l}\text { Risk minimization } \\
1 \text { Designing a risk management strategy } \\
2 \text { Choosing the best strategy } \\
3 \text { Strategy implementation }\end{array}$ & Aim - risk optimization \\
\hline Stage 4 & $\begin{array}{l}\text { Risk control (NT and TD) } \\
1 \text { Risk Monitoring } \\
2 \text { Reassessment and adjustment of risks } \\
3 \text { Operational Decline Decisions }\end{array}$ & \\
\hline
\end{tabular}

Fig. 5. Risk management algorithm $[16,17]$ : NT - non-destructive testing; TD - technical diagnostics

Risk registration and risk processing (recommended table form)

\begin{tabular}{|c|c|c|c|c|c|c|c|c|c|c|c|c|c|c|c|}
\hline \multirow[b]{2}{*}{$\begin{array}{l}\text { De- } \\
\text { part- } \\
\text { ment }\end{array}$} & \multirow[b]{2}{*}{$\begin{array}{l}\text { Risk } \\
\text { cate- } \\
\text { gory }\end{array}$} & \multirow[b]{2}{*}{$\begin{array}{l}\text { Sub- } \\
\text { cate- } \\
\text { gory }\end{array}$} & \multirow{2}{*}{$\begin{array}{l}\text { Risk } \\
\text { de- } \\
\text { scrip- } \\
\text { tion }\end{array}$} & \multirow[b]{2}{*}{$\begin{array}{l}\text { Risk } \\
\text { conse- } \\
\text { quence }\end{array}$} & \multicolumn{3}{|c|}{ Currently } & \multirow[b]{2}{*}{$\begin{array}{c}\text { Risk } \\
\text { owner }\end{array}$} & \multirow{2}{*}{$\begin{array}{c}\text { The } \\
\text { following } \\
\text { mitigation } \\
\text { actions }\end{array}$} & \multirow[b]{2}{*}{$\begin{array}{l}\text { Mitiga- } \\
\text { tion } \\
\text { owner }\end{array}$} & \multirow{2}{*}{$\begin{array}{l}\text { Demand } \\
\text { is a } \\
\text { source of } \\
\text { risk }\end{array}$} & \multirow[b]{2}{*}{$\begin{array}{l}\text { Dead- } \\
\text { lines }\end{array}$} & \multicolumn{3}{|c|}{ Targets } \\
\hline & & & & & $\begin{array}{l}\text { Proba- } \\
\text { bility }\end{array}$ & $\begin{array}{l}\text { Influ- } \\
\text { ences }\end{array}$ & $\begin{array}{l}\text { Risk degree= } \\
=\text { probability } \\
\text { of exposure }\end{array}$ & & & & & & $\begin{array}{l}\text { Proba- } \\
\text { bility }\end{array}$ & $\begin{array}{l}\text { Influ- } \\
\text { ences }\end{array}$ & $\begin{array}{c}\text { Target level } \\
\text { of risk after } \\
\text { mitigation }\end{array}$ \\
\hline 1 & $\cdots$ & $\cdots$ & $\ldots$ & $\ldots$ & $\ldots$ & $\cdots$ & $\ldots$ & $\cdots$ & $\ldots$ & $\ldots$ & $\cdots$ & $\ldots$ & $\ldots$ & $\ldots$ & $\ldots$ \\
\hline 2 & $\cdots$ & $\cdots$ & $\ldots$ & $\ldots$ & $\ldots$ & $\cdots$ & $\ldots$ & $\ldots$ & $\ldots$ & $\ldots$ & $\ldots$ & $\ldots$ & $\ldots$ & $\ldots$ & $\ldots$ \\
\hline
\end{tabular}

\section{Conclusions}

During the study, an algorithm for the formation of risk during the operation of welded structures is constructed. The parameters of the ultimate state of the welded structure from mechanical stresses and the quality indicators of corrosion effects are determined. The calculated formulas for the speed (probability) of reaching limit states from mechanical stresses are selected. It is recommended to use the Bayesian grid method to analyze a combination of actions. It has been established that one of the main tasks of the welding production quality management system is to ensure the identification of potential inconsistencies in the welding production system and to prevent their detection using risk management. Since deviations in the processes of the management system are the reasons for the formation of a shortage of products and the risk of an emergency when operating welded structures.

\section{Acknowledgement}

Thanks to the company LLC «Strategy BM» (Kyiv, Ukraine) for the implementation of the quality and risk management system according to DSTU ISO 9001:2015 and the previous provision of information for the study.

\section{References}

1. Vitkin, L., Lapach, S. (2007). Yak vyznachyty stupin nebezpeky produktsii. Standartyzatsiia, sertyfikatsiia, yakist, 3, 48-54.

2. Kriukon, N., Shadrin, A. (2006). Menedzhment riska kak instrument postoiannogo uluchsheniia. Standarty $i$ kachestro, $2,74-77$.
3. Chaika, I. I. (2014). Standart ISO 9001:2015. Chto nas ozhidaet? Standarty $i$ kachestro, 6, 18-20.

4. Khei Khempton, D. M. Shag vpered s ISO 9001:2015. Available at: http://www.klubok.net/article2722.html

5. DBN V.1.2-14:2018. Systema zabezpechennia nadiinosti ta bezpeky budivelnykh obiektiv. Zahalni pryntsypy zabezpechennia nadiinosti ta konstruktyonoi bezpeky budivel ta sporud. Nadano chynnosti 01.01.2019 (2018). Kyiv: Ministerstvo rehionalnoho rozvytku, budivnytstva ta zhytlovo-komunalnoho hospodarstva Ukrainy, 36.

6. Development of Methods of Risk Detection Assessment in the Welding (2017). Düsseldorf: LEP LUMBERT Academic publishing, international book market service LTD, 98.

7. AS/NZS 4360:2004. Risk management (2004). ISO, 28.

8. Bondarenko, Yu. K., Kovalchuk, O. V. (2019). Doslidzhennia vplyvu dzherel ryzykiv na tekhnichnu bezpeku zvarnykh konstruktsii pry ekspluatatsii z vykorystanniam NK i TD. Neruiniznyi kontrol ta tekhnichna diahnostyka. Kyiv, 245-250.

9. ISO 31000:2018 Risk management - Guidelines. Available at: https://www.iso.org/ru/standard/65694.html

10. Bondarenko, Yu. K., Kovalchuk, O. V. (2017). Otsinka ryzyku ekspluatatsii zvarnykh konstruktsii na pidstavi monitorynhu protsesiv upravlinnia yakistiu i provedennia vyprobuvan metodamy NK i TD. Neruinionyi kontrol ta tekhnichna diahnostyka, 3, 56-63.

11. Bondarenko, Yu. K., Kovalchuk, O. V (2017). Metodyky otsinky i rozpiznavannia ryzykiv $\mathrm{v}$ zvariuvalnomu vyrobnytstvi z metoiu stvorennia reiestru i ranzhuvannia ryzykiv $\mathrm{v}$ zvarnykh konstruktsiiakh. Yakist, standartyzatsiia, sertyfikatsiia kontrol. teoriia i praktyka. Odessa, 37-42.

12. DSTU EN ISO 9001:2018. Systemy upravlinnia yakistiu. Vymohy (EN ISO 9001:2015, IDT; ISO 9001:2015, IDT). Available at: http://online.budstandart.com/ua/catalog/doc-page?id_ doc $=79941$ 
13. ISO/IEC 31010:2019. Risk management - Risk assessment techniques. Available at: https://www.iso.org/ru/standard/72140.html

14. CSA Q 850:1997. Risk Management Guidelines for Decision Makers (1997)

15. JIS Q 2001:2001. Guidelines for development and implementation of risk management system (2001). Japanese Standards Association.

16. Potapjevskii, A. G., Bondarenko, Y. K., Loginova, Y. V., Artjukh, K. O. (2016). Technological Control Of Quality And Service Properties Of Products In Welding Production. Tekhnicheskaia diagnostika i nerazrushaiuschii kontrol, 4, 56-61. doi: http://doi.org/10.15407/tdnk2016.04.10

17. Bondarenko, Yu. K., Bilokur, I. P., Medvedeva, N. A. (2016). Diagnostika i monitoring tekhnicheskogo sostoianiia svarnykh truboprovodov dlia ocenki sootvetstviia normativnym dokumentam. Kachestvo, standartizaciia, kontrol, teoriia $i$ praktika. Odessa, 19-28.

Bondarenko Yuriy, PhD, Leading Researcher, Laboratory of Reliability of Welded Structures and Mechanical Tests, E. O. Paton
Electric Welding Institute of the National Academy of Sciences of Ukraine, Ukraine, e-mail: office@paton.kiev.ua, ORCID: http:// orcid.org/0000-0002-8758-9924

Kovalchuk Oksana, Junior Researcher, Laboratory of Reliability of Welded Structures and Mechanical Tests, E. O. Paton Electric Welding Institute of the National Academy of Sciences of Ukraine, Kyiv, Ukraine, e-mail: office@paton.kiev.ua, ORCID: http:// orcid.org/0000-0002-4350-2217

Loginova Yuliya, Junior Researcher, Laboratory of Reliability of Welded Structures and Mechanical Tests, E. O. Paton Electric Welding Institute of the National Academy of Sciences of Ukraine, Ukraine, e-mail: office@paton.kiev.ua, ORCID: http://orcid.org/0000-00021023-3663

Artiukh Karyna, Leading Technologist, Laboratory of Reliability of Welded Structures and Mechanical Tests, E. O. Paton Electric Welding Institute of the National Academy of Sciences of Ukraine, Ukraine, e-mail: office@paton.kiev.ua, ORCID: http:// orcid.org/0000-0002-0760-1760 